\title{
Digital public relations through the lens of affordances: A conceptual expansion of the dialogic principles
}

\author{
Alvin $\mathrm{Zhou}^{1}$ and Sifan $\mathrm{Xu}^{2}$ \\ ${ }^{1}$ Hubbard School of Journalism and Mass Communication \\ University of Minnesota \\ ${ }^{2}$ College of Communication and Information \\ University of Tennessee, Knoxville
}

\begin{abstract}
Author Note
Please cite the journal publication: Zhou, A., \& Xu, S. (2021). Digital public relations through the lens of affordances: A conceptual expansion of the dialogic principles. Fournal of Public Relations Research. https://doi.org/10.1080/1062726X.2022.2046585

We thank the editor and anonymous reviewers for their thoughtful comments. The manuscript's previous versions, circulated as "Remaking dialogic principles for the digital age: The role of affordances in dialogue and engagement" and "Digital public relations through the lens of affordances: A conceptual update of the "ease of interface" dialogic principle," were presented at the 69th annual meeting of the International Communication Association as the Top Faculty Paper of the Public Relations Division and the recipient of the Robert Heath Award.
\end{abstract}




\begin{abstract}
Connecting the affordance framework in computer-mediated communication to public relations theories, this essay proposes an affordance perspective on dialogic communication and digital public relations in general. We argue that 1) the enactment of organization-public dialogue on digital platforms requires certain combinations of media affordances; 2) the lens of affordances facilitates a non-dichotomous examination of the "dialogic communication vs. digital media" debate; 3) the fifth dialogic principle "ease of interface" should be conceptually expanded to “favorable affordances," which asserts that public relations practice should evaluate digital media platforms' various action possibilities and consider their inherent potentials for organization-public relationship building; and 4) research on digital public relations should incorporate affordance theory to achieve cross-platform theorization.

Keywords: Affordances, Digital Public Relations, Social Media, Dialogue, Dialogic Communication, Dialogic Principles
\end{abstract}




\section{Digital public relations through the lens of affordances:}

\section{A conceptual expansion of the dialogic principles}

Social media has dramatically changed the landscape of public relations practice and spawned much interest from public relations scholars (e.g., Bortree \& Seltzer, 2009; Kent \& Saffer, 2014; Sommerfeldt \& Xu, 2017). The plethora of research has contributed to many areas such as nonprofit public relations (e.g., Lovejoy et al., 2012), digital activism (e.g., Xiong et al., 2019), and socially mediated public discourses (e.g., Xu \& Zhou, 2020).

Initially proposed to reconsider public relations ethics (Kent \& Taylor, 2002) and address digital public relations practice via website communication (Kent \& Taylor, 1998), the dialogic theory and digital dialogic principles have long been adopted and adapted to evaluate organizations' communication practice on social media (e.g., Men et al., 2018; Theunissen, 2015; Wirtz \& Zimbres, 2018). However, the adaptation of dialogic concepts proposed at the dawn of the World Wide Web to more-recent digital media developments is anything but a triumph. First, in the stream of research probing the communication of organizations' dialogic orientations, scholars have started critiquing the blanket use of the term "dialogue" in social media studies, considering the interpersonal nature of dialogue inherently unsuitable for digital contexts, and arguing that "digital dialogue" is an oxymoron (e.g., Kent \& Theunissen, 2016; Lane, 2020; Theunissen \& Wan Noordin, 2012). Second, in the stream of research probing the application of digital dialogic principles for public relations practice, the "ease of interface" principle has gradually lost its relevance and received little to no scholarly attention for years (Sommerfeldt \& Yang, 2018), with researchers seeming to completely ignore the principle because the social media interface remained "indiscriminate and by default" (i.e., constant) throughout their studies (e.g., Rybalko \& Seltzer, 2010; Wang \& Yang, 2020; Watkins, 2017; Yue et al., 2021).

Opportunities to advance the dialogic theory, digital dialogic principles, and the broader public relations research in digital contexts thus reside in the reconciliation of this theoretical tension. Through the lens of affordances developed in psychology and human-computer 
interaction research, which breaks down digital media platforms into various sets of action possibilities, the purpose of this conceptual piece is to examine and expand the "ease of interface" principle to "favorable affordances" for the current media environment, and discuss new ways forward to theorize organization-public relationship building in the digital space. Going beyond the dialogic theory, this conceptual piece also unpacks how the affordance theory can inform digital public relations research in general, and argues that examining public relations practice from the lens of affordances can enable cross-platform comparisons and provide platform-agnostic insights on how digital media affect our profession.

The essay is structured as follows. In the first section, we briefly review two camps of public relations research on dialogic communication-one focusing on the enactment of dialogue as a relational orientation (originating from Kent \& Taylor, 2002) and the other focusing on the principles for communication practice (originating from Kent \& Taylor, 1998) - and differentiate them to provide some background for our arguments. In the second section, we explicate the problem this conceptual article tries to address-the incompatibility of dialogic concepts with digital media. In the third section, we invoke the affordance theory and summarize how the affordance lens has been used in recent research to understand the role of information communication technologies (ICTs) in our digital lives. In the fourth section, we provide suggestions on how to incorporate affordances into the discussion of digital dialogue. In the last section, we articulate our ultimate goal of bringing affordance theory into the research agenda of digital public relations.

\section{Dialogue, Dialogic Communication, and Digital Dialogic Principles}

Public relations scholars started writing about dialogue around the early 1990s (e.g., Pearson, 1989b), but the development of its formal theory mostly took place around the 2000s (e.g., Kent \& Taylor, 2002). The concept of dialogue emphasizes the relational orientation of communicative activities and is based on a different set of underlying philosophies from the 
then-dominant paradigm of two-way symmetrical communication ${ }^{1}$ (see Grunig \& Hunt, 1984; Theunissen \& Wan Noordin, 2012). The proposal of the dialogic theory advanced the idea that, by building mutual understanding and promoting ethical communication between organizations and their publics, public relations practice could create dialogue as a product that contributes to beneficial relationships and social capital that are desirable for publics, organizations, and the general society (Kent \& Lane, 2017; Taylor, 2011; Taylor \& Kent, 2014). The ubiquity of the term "dialogue" at that time was seen as a signal of a paradigm shift in public relations, as scholars increasingly considered public relations as a communication tool for relationship negotiation rather than a mere management function.

Kent and Taylor (2002) contended that genuine dialogue followed the features of mutuality, propinquity, empathy, risk, and commitment. Mutuality means that organizations and publics should collaborate with intersubjectivity and maintain a relationship with mutual equality; propinquity addresses the rhetorical process of dialogic exchanges, and contends that organizations and publics should consult each other before decision making; empathy alludes to the atmosphere of support and trust that is a requirement for successful dialogic communication between organizations and publics; risk denotes the unpredictability of dialogic communication and the vulnerability of organizations and publics as dialogic entities; and commitment refers to organizations' and publics' commitment to their relationship, conversations, and interpretations, which oftentimes requires physical resources devoted by each party. Therefore, dialogue-the somewhat abstract concept rooted in moral philosophy, interpersonal communication, and rhetoric literature (e.g, Buber, 1970; Kent \& Taylor, 2002; Stewart, 1978) - is an orientation and should be considered an ideal that guides ethical public relations practice, although it might be difficult or even impossible to achieve the ideal in the real world (e.g., Botan, 1997; Ciszek, 2020; Lane \& Bartlett, 2016; Theunissen \& Wan Noordin, 2012). The word orientation usually refers to a person's interest, opinion, and belief in a

\footnotetext{
${ }^{1}$ The model of two-way symmetrical communication has since been updated to characterize various dimensions of public relations behaviors (cf. Grunig, 2001; Huang, 2001, 2004; Rhee, 2002; Sha, 2007, 2009).
} 
particular topic (Cambridge University Press, n.d.). In our context, orientation refers to an organization's relational tendency to and belief in establishing an ethical public communication program and achieve mutual understanding with its publics (cf. Taylor \& Kent, 2014). Dialogic communication, accordingly, refers to communication practice that carries dialogic orientations and builds and sustains dialogues between organizations and their publics.

Along with the conceptual development, in another article (Kent \& Taylor, 1998), these authors also drafted five digital dialogic principles that they argued could help online relationship building between organizations and publics, on one hand to help scholars empirically examine possible traits of dialogic communication, and on the other hand to address the increasing use of the World Wide Web for public relations. The word principle means a rule or code of conduct (Merriam-Webster, n.d.). Practice that does not follow those tangible rules will be seen as "against the principle." In our context, the term principle refers to the (five) rules that practitioners should follow and against which their content creation should be benchmarked (see Wirtz \& Zimbres, 2018). The five principles are: (a) dialogic loops, which refer to the use of communication channels through which organizations ask for opinions, solicit feedback, and address questions from their publics; (b) useful information, which requires organizations to provide valuable information that is wanted by their publics; (c) return visit generation and (d) visitor conservation, which refer to communication strategies that encourage repeated visits and keep visitors on-site for a longer time; and (e) ease of interface, which taps into the technical aspect of dialogic communication and suggests that websites should be easy to navigate and user-friendly.

However, the dialogic public relations theory (Kent \& Taylor, 2002) should not be conflated with the five digital dialogic principles (Kent \& Taylor, 1998) analyzed by numerous studies throughout the years (see Ao \& Huang, 2020; McAllister-Spooner, 2009; Wirtz \& Zimbres, 2018, for summaries). The five principles-dialogic loops, useful information, visitor conservation, return visit generation, and ease of interface-are merely communication strategies suggested for organizations to use on the Internet. Online communication that fulfills 
these five principles is not necessarily dialogic communication, and digital dialogic communication does not have to fulfill all of these five principles.

As later critiqued by the original authors and others, the five digital dialogic principles spawned the "fairly common functionalist orientations toward dialogue" (Kent \& Lane, 2017, p. 572), and it is time to consider the 2002 article as a theoretical revision to the 1998 proposal and move forward the development of dialogue as a public relations theory instead of online communication rules (Lane, 2018). The word theory here means a set of implicit and explicit assumptions to interpret and evaluate empirical evidence (Kent \& Taylor, 2002; Kuhn, 2010), and the dialogic theory refers to the normative assumptions in public relations research that organization-public communication is the most ethical when it resembles the relational nature of interpersonal dialogue. Given that publications on how organizations use digital dialogic principles on websites and social media platforms clearly outnumber those devoted to the theoretical development of dialogue, it is indeed unfortunate that a set of strategies for digital practice-proposed at the dawn of the Internet age to recognize its potential for relationship building-overshadowed theoretical arguments about genuine dialogue and stifled the development of the dialogic theory in public relations research (e.g., Sommerfeldt \& Yang, 2018; Theunissen \& Wan Noordin, 2012; Wirtz \& Zimbres, 2018).

Nonetheless, guided by these five communication principles, researchers have contributed a huge amount to our understanding of how digital public relations practice has been carried out by professionals. Their empirical assessments seem to reach the consensus that organizational communication on digital outlets, such as websites, Facebook, and Twitter, did not utilize the full potential of these platforms for potential dialogic communication. For instance, Lovejoy et al. (2012) found that, although nonprofit organizations were utilizing hyperlinks, hashtags, retweets, and other communication tools to engage with publics, the sampled organizations mostly used Twitter as a one-way communication channel, with little evidence of using dialogic features or building relationships. These researchers' studies-mostly content analyses of organizations' websites and social media posts-constitute such a large 
portion of existing knowledge of digital public relations that it would be remiss to neglect this body of literature and the original five dialogic principles, if we are about to discuss the implications of affordances for digital public relations research. Therefore, in the following sections, we divide our discussions into two separate but interrelated arguments about how the affordance framework can help public relations researchers grapple with difficult questions regarding both the dialogic theory and the five digital dialogic principles.

In short, the five digital dialogic principles are practical suggestions made by Kent and Taylor (1998) that could be helpful for the enactment of genuine dialogues between organizations and their publics theorized by Kent and Taylor (2002). Or as Sommerfeldt and Yang (2018) simply put it, dialogue is a promise, while dialogic communication is the procedural steps and communicative conduct that fulfills and precedes that promise; and the five digital dialogic principles are a set of suggested strategies to build dialogues in the specific setting of the World Wide Web.

The current essay argues that the affordance theory developed in psychology and popularized by the literature in sociology and computer-mediated communication has profound implications for all these dialogic concepts and the general field of digital public relations, and that using the affordance framework can help release some tension between the term "dialogue" and "digital" which will be discussed in the following section. In Table 1, we summarize our arguments for easy reference.

[Insert Table 1 Here]

\section{Interrogating the Compatibility of Dialogic Concepts with Digital Media}

In the previous section, we summarized two camps of public relations research that employed the dialogic vocabulary, the first concerning the philosophical discussion on what organization-public dialogue means (i.e., dialogue and dialogic communication) and the second concerning the best practice of building (potential) dialogue on the World Wide Web (i.e., digital dialogic principles). In the next two subsections, we interrogate the applicability of those 
dialogic concepts in the digital media context, and argue that the recent development of ICTs has created several compatibility issues between digital media and both research traditions.

\section{Dialogue and Dialogic Communication with Digital Media}

The incompatibility of dialogic communication-the communication practice that builds and sustains dialogues between organizations and publics and that features the orientation of risk, mutuality, propinquity, empathy, and commitment-with digital media stems from the fact that dialogue is a concept deeply rooted in interpersonal communication and that dialogic communication as an ideal for public relations ethics was initially modeled for face-to-face practice (e.g., Buber, 1970; Pearson, 1989a). Dialogue from its very beginning was not theorized for computer-mediated communication, and to adapt the concept for the digital age, we need new theoretical frameworks.

Some scholars, when reviewing studies that conflated dialogue with digital dialogic principles, have argued that it might be completely unsuitable to discuss dialogue and dialogic communication in the context of digital media. For example, Kent and Theunissen (2016) provided a pessimistic view of enacting dialogue through social media. Since YouTube, Twitter, and Instagram do not provide sufficient reciprocal self-disclosure that is a requirement for dialogue, Kent and Theunissen (2016) argued that dialogue might not be even possible on these channels. Just as suggested by its title-Elegy for Mediated Dialogue, Kent and Theunissen's (2016) critique seems to claim that "mediated dialogue" is a self-contradictory concept, that there is no way out of the conflict between genuine dialogue and computer-mediated communication, and that researchers should not talk about dialogue in studies on social media or other digital public relations topics.

In response, we offer two arguments, on one hand to engage in the continuing scholarly debate on dialogue and computer-mediated communication, and on the other hand to set the stage for our central argument of incorporating affordance theory into the discussed public relations paradigm.

First, the absence of dialogue on social media is not a sufficient reason to cease the 
scholarly discussion about dialogue in digital space. Dialogues between organizations and publics are hard to find, not only in online settings, but also in offline practice. For example, dialogue has not been carefully and systematically examined by extant literature. In other words, the incompatibility of dialogue and dialogic communication with digital media can be, at least partially, attributed to some characteristics of digital media, and public relations scholars 
are recommended to use theoretical frameworks in computer-mediated communication to address this incompatibility.

Tension between theories and practice creates opportunities for the entry of new conceptual frameworks, and we argue that the inherent incompatibility of dialogue and dialogic communication with digital media is one such tension. To address this tension, researchers need insights from other fields that have not (yet) been extensively referenced by public relations scholarship, such as computer-mediated communication and human-computer interaction (cf. Pang et al., 2018). By examining this tension both critically and empirically with interdisciplinary inquiries, scholars can improve the dialogic theory's compatibility with, and provide more concrete suggestions for, the increasingly digital practice of public relations. In later sections, we provide one of the first attempts at addressing this tension, by considering how different affordances of digital media affect the enactment of dialogue. Moreover, we believe that the discussion of digital dialogue provides possibilities for public relations researchers to contribute in turn to the development of digital media theories at large.

\section{Digital Dialogic Principles with Digital Media}

The incompatibility of digital dialogic principles-dialogic loops, useful information, visitor conservation, return visit generation, and ease of interface-with digital media manifests itself by the fact that the "ease of interface" principle appears to have been largely ignored by extant scholarship.

Kent and Taylor (1998) initially devised the five principles for the Web 1.0 era, which was characterized by the monopoly of power in content creation with website communication representing its notable features (see Cormode \& Krishnamurthy, 2008). At that time, the majority of organizational stakeholders simply visited a website address and consumed information designed by the organization's website programmers. In contrast, the concept of Web 2.0, proposed in the mid-2000s (cf. O’Reilly, 2005) and enabled by new programming technologies such as JavaScript (Allen, 2013), arrived far later than Kent and Taylor (1998). Though the term Web 2.0 and its relationship with Web 1.0 are constantly contested (e.g., Allen, 
2008), it is mostly agreed upon that Web 2.0 is distinct with its democratic and social nature by enabling mass participation from all Internet users, prominent examples being social media platforms such as Facebook and Twitter (Barassi \& Treré, 2012; Cormode \& Krishnamurthy, website communication (e.g., Ingenhoff \& Koelling, 2009; Seltzer \& Mitrook, 2007).

When examining digital dialogic principles on social media, scholars clearly had some struggles adapting these principles. One of the earliest studies looked at Fortune 500 companies' stakeholder engagement on Twitter (Rybalko \& Seltzer, 2010). To examine the use of dialogic principles in Twitter profiles and individual tweets, the researchers gauged organizations' implementation of "dialogic loops" by evaluating their responsiveness to user requests, and "useful information," "visitor conservation," and "return visit generation" by coding links and media content presented in theirs tweets, with later articles following this operationalization on 
Twitter, WeChat, and other social media platforms (e.g., Qu, 2020; Yue et al., 2019).

One major defect of this operationalization is the neglect of the "ease of interface" principle. Starting from Rybalko and Seltzer's (2010) study on Twitter, scholars appear to have completely discarded the principle from their studies (e.g., Gálvez-Rodríguez et al., 2018; Linvill et al., 2012; Men et al., 2018; Watkins, 2017), as noted by Wirtz and Zimbres’s (2018) review. Admittedly, studies focusing on one single platform do not require careful examinations of the platform's action possibilities, because the social media interface will remain the same across users and throughout the studied time period. But the seeming irrelevance of the "ease of interface" principle is concerning, to say the least, and it is not helping scholars theorize digital public relations or helping practitioners understand the influence of communication technology on their work.

"Ease of interface" might fit well with the Web 1.0 era, back when public communication on official websites was not always user-friendly. But two decades later, websites have been designed to near perfection, and malfunctions are much less likely to happen, but different platforms (e.g., official websites, social media sites, etc.) still have dramatically different user experiences that are affecting the practice of dialogic communication in the digital space. Facebook, for instance, seems to be a better social media platform to fulfill the dialogic loop principle than Twitter (e.g., Briones et al., 2011), and there is accumulating evidence showing that the differences of organizations' communication practices across platforms might stem from the platforms themselves (e.g., Auger, 2013).

We thus argue that these cross-platform differences and nuances brought by emerging media cannot be reduced to an issue caused by mere interface, and the "ease of interface" principle apparently falls short of a meaningful suggestion for public relations practice. Sommerfeldt and Yang (2018) shared the same viewpoint in a recent special issue on digital dialogic communication theory:

Many studies utilizing the principles choose to simply omit the "ease of interface" principle, as digital platforms like Facebook and Twitter provide the same interface 
for all users. A substantial extension of dialogic communication theory might, therefore, come from a deeper consideration of the unique characteristics of the social media communication context and their match or mismatch with dialogic principles ... In any case, scholars should begin to question the applicability of the principles to the social media environment, and adapt-or even remake-them accordingly. (p. 61)

We echo this view and argue that the moot "ease of interface" principle should be expanded to deliver a contemporary understanding of digital dialogic communication's technical requirements, and its decreasing relevance in recent studies is inviting new proposals that go beyond existing theoretical frameworks in public relations. Responding to Sommerfeldt and Yang's (2018) call to address the incompatibility between the digital dialogic communication principles and the current digital media context, we provide a conceptual expansion of the "ease of interface" principle to "favorable affordances," as explained in the following sections.

\section{Affordance Theory}

The theoretical framework of affordances was initially developed by James J. Gibson (1979) for an interactionist view of perception and action in ecological psychology (Greeno, 1994). While reviewing and summarizing Gibson's work, Greeno (1994) defined affordances as a property of the environment that interacts with agents in such a way that activities can be supported. Evans et al.'s (2017) interpretation was more straightforward: an affordance means "an action possibility available in the environment" (p. 37).

The concept of affordances has been adapted into many other disciplines, especially product design and human-computer interaction. Communication scholars have used the term "affordances" to illustrate the distinguished and socially constructed characteristics of various communication channels and to examine the effects of their interactive features on human communication. For example, generally speaking, portable technologies and mobile communication are affording flows of information free from geographical restrictions, and social media are affording interactive and networked communication behaviors that could not 
be realized before (e.g., Campbell, 2013; Humphreys, 2007). More empirically in the literature on organizations, Fulk and Yuan (2013) connected affordance theory and knowledge sharing literature, and they argued that enterprise social networking systems could afford better social connections, create and sustain social capital, and improve knowledge sharing among employees. Treem and Leonardi (2013) compared social media with other workplace communication technologies, such as emails, instant messaging, and teleconferencing, and concluded that social media afforded better organizational communication with higher levels of visibility, editability, persistence, and association.

As platform affordances are granting organizations and individuals abilities to commit certain communicative actions, there also comes the discussion of platforms' constraints and the consequent inabilities. One notable example of social media's affordance constraints is the character limit set by Twitter, where users were unable to post tweets longer than 140 characters. Studies have found that the constraint limited the possibility of in-depth political deliberation (Jaidka et al., 2019), thorough user self-presentation (Evans et al., 2017), and engaging organizational communication (Lovejoy \& Saxton, 2012). However, constraints are not necessarily negative for mediated communication. In fact, constraints can sometimes grant distinguished characteristics to media platforms, and contribute to their commercial success. For example, messages disappear after a few seconds on Snapchat, which indeed is a constraint, but it makes the platform unique and popular among millennials (McCormick, 2021). Some recent publications have also argued that constraints can encourage individual creativity and improve content quality (e.g., Gligorić et al., 2018; Joyce, 2009).

Some public relations scholars have implicitly used the concept of affordances in their studies. For example, in a review of literature on organizational social media use, Paek et al. (2013) concluded that "practitioners are not taking full advantage of the interactive and dialogic capabilities afforded by new media platforms" (p. 527). The phrase "interactive and dialogic capabilities" is close to the meaning of affordances. However, the concept is still largely scant in published public relations scholarship, and it has not been extensively discussed in regard to the 
theory of dialogue or the practice of dialogic communication.

We believe a critical assessment of how different affordances interact to regulate individuals' and organizations' action possibilities on digital media platforms and how they positively or negatively affect communication outcomes can inform theory building in public relations. Moreover, the relational outcome of communication actions, which is paramount to public relations research, has been left unattended by previous digital media scholarship. By studying how affordances affect dialogic outcomes (i.e., the communication of the risk, mutuality, propinquity, empathy, and commitment orientations) and dialogic principles (i.e., dialogic loops, useful information, visitor conservation, and return visit generation), public relations scholars can not only have a deeper understanding of how dialogue works (or why dialogue does not work) on digital media platforms, but also inform the general digital media scholarship by providing insights on how affordances affect relationship building.

\section{Suggestions from an Affordance Perspective of Dialogic Communication}

In the next two subsections, we provide further discussions on how to use the affordance theory to examine dialogic concepts. In the first subsection, in response to Kent and Theunissen (2016), we specify how the affordance perspective provides new insights to dialogic public relations theory (Kent \& Taylor, 2002) and how scholars can push the field forward with empirical studies that incorporate the affordance theory. In the second subsection, in response to Sommerfeldt and Yang (2018), we propose a conceptual expansion of the "ease of interface" dialogic principle (Kent \& Taylor, 1998) to "favorable affordances," argue that it provides a more complete and critical understanding of how affordances affect digital public relations, and encourage practitioners to assess affordances of emerging digital media platforms before utilizing them for public relations purposes.

\section{Communicating Dialogic Orientations with Digital Media Affordances}

We argue that the enactment of dialogue in the online space requires certain kinds of digital media affordances. However, what affordances help enact digital dialogue and what affordances inhibit it remain open questions, and public relations scholars are particularly 
equipped and suited to answer these research questions at the intersection of digital technology and relationship building.

In a scale development study, Fox and McEwan (2017) considered media affordances in approach (e.g., O’Sullivan, 2000; Park et al., 2019; Schultz et al., 2011; Sommerfeldt et al., 2019; Yuan, 2011), is that the affordance approach is platform agnostic and easily applicable to different digital media channels currently employed in public relations practice. In other words, the framework focuses on the communicative properties of digital media, rather than its relationship building can be applied to multiple digital channels with that specific affordance, which can contribute to our general understanding of how digital media affects organization-public relational efforts such as dialogic communication, rather than our 
knowledge about one specific communication channel.

For example, Kent and Theunissen (2016) proposed the idea that self-disclosure might be a requirement for forming relationships and building dialogues. By employing the affordance framework and empirically testing if anonymity, the opposite of self-disclosure, inhibits the communication of dialogic orientations (e.g., empathy and propinquity) through experiments or survey studies, scholars might be able to generalize their findings and test the hypothesis that existing communication channels that afford anonymity will all curb the enactment of dialogue. Similarly, the requirement of physical presence in dialogue (Kent \& Theunissen, 2016) corresponds to the social presence affordance, mentioned multiple times by public relations scholars but outside of the affordance framework (e.g., Men et al., 2018). Though social presence might never amount to the normative requirement of physical presence drafted by moral philosophers on dialogue, we believe how the level of social presence afforded by digital channels takes organization-public interactions closer to or further from organization-public dialogue is still a worthy question to ask, in order to understand the role of new media technology in public relations. By empirically establishing that, for instance, social presence facilitates the communication of mutuality and risk, we can better pinpoint why video conferencing platforms (e.g., Zoom and Skype) should be used to achieve the dialogic ideal during organizational crises. By studying how media affordances influence these relational outcomes, we can also inform the design of new media technologies, such as how we should program intelligent organizational tools (e.g., chatbots) for public communication purposes. In other words, instead of making platform-specific claims (e.g., Twitter is not dialogic; Kent and Lane, 2017), we encourage scholars to delve more deeply into the question of why dialogue does not emerge on digital platforms, ask what properties of the studied platform make it dialogic or not dialogic, and attribute the answer to affordances-the building blocks of digital media pertaining to their action possibilities. We believe these affordance-based findings will provide more theoretical insights about the role of information technology in dialogic communication than those platform-specific claims presented by existing literature. 
In fact, employing the scale developed by Fox and McEwan (2017), scholars have started explicitly examining affordances in organizational settings that are of great interest to public relations scholars, and these studies have yielded theoretical insights that can be applied to multiple digital channels. By experimentally manipulating participants' perceived levels of anonymity and visibility, Mao and DeAndrea (2019) evaluated the effects of the two affordances on employees' intention to voice work-related concerns, and found that these two affordances can significantly alter employee behavior through their influences on channel safety and individual efficacy. Though the main finding is confirmative and intuitive, their study also found counterintuitive results, such as the visibility affordance decreased individual efficacy, which opened up new space for future research on the causal effect of affordances in employee communication.

Similarly, scholars working in the field of digital public relations can connect the social affordance scale with measurements on dialogic communication (e.g., Romenti et al., 2016; Yang et al., 2015) and investigate these affordances' (and their interactive) effects on relational outcomes. While much digital media scholarship has theorized or examined outcomes such as psychological perceptions, organizational resources, political representation, civic engagement, and online discussions (e.g., Deseriis, 2021; Jaidka et al., 2019; Lelkes, 2020; Rice et al., 2017; Wohn et al., 2016) affordances' effects on relationship building have been largely unattended. We believe this lacuna presents itself as a great opportunity for public relations scholarship to contribute back to the general study of digital media effects.

There are two other advantages of using affordances to examine digital dialogue. First, the theoretical framework is a promising candidate for a general theory of emerging media, as it has been successfully employed to dissect media effects spawned by newly developed technologies, such as virtual reality and augmented reality (e.g., Barreda-Ángeles et al., 2021; Scholz \& Smith, 2016; Steffen et al., 2019). Using a somewhat future-proof concept to understand the influence of communication technology on dialogue can provide more theoretical consistency throughout the literature. Second, the term is ubiquitous across fields 
that are related to public relations, not only in the communication literature referenced above, but also in fields such as management, marketing, and information systems (e.g., Anderson \& Robey, 2017; Argyris \& Monu, 2015; De Luca et al., 2021; Leidner et al., 2018; Leonardi \& Vaast, 2017). By using the same theoretical framework, public relations scholarship can better engage with the wider social science literature.

In summary of this section, we encourage scholars to examine the mediated communication of dialogic orientations (i.e., mutuality, propinquity, empathy, risk, and commitment) through the lens of affordances, in order to address the incompatibility between the normative theory of dialogue and the increasingly digital practice of public relations. How a normative theory-developed to conceptualize offline practice ideals-can be adapted for a digital world has presented many challenges for communication scholars. Just like how the literature on political deliberation is getting adapted to accommodate digital channels with the affordance framework (e.g., Halpern \& Gibbs, 2013; Jaidka et al., 2019; Maia \& Rezende, 2016; Rossini, 2020), we contend that public relations scholars should also start speaking the language of affordances and examining the effect of digital media channels on the communication of dialogic ideals with this platform-agnostic approach.

\section{From "Ease of Interface" to "Favorable Affordances": A Conceptual Expansion} 2.0 era, we propose using "favorable affordances" instead to help practitioners assess the action possibilities of media channels and reevaluate their digital dialogic communication practice.

"Ease of interface" is a part of "favorable affordances," which incorporates all facets of the human-computer interaction in digital dialogic communication. Interface is a small part of the affordance framework, incorporated as the "accessibility" affordance in Fox and McEwan's (2017) typology. Without ease of interface, a particular platform must not have the affordances needed to provide smooth experiences for dialogic communication to materialize. But the ease of interface does not necessarily translate to the platform having a favorable condition for the conduct of dialogic communication. 
As previously discussed, platforms in the Web 2.0 era offer organizations the same set of features and interfaces, and organizations build upon them to communicate and build relationships with publics. It is indeed how organizations utilize these features (i.e., the other four digital dialogic principles), rather than whether the interface is easy to use, that is yielding different public relations outcomes. By conceptually expanding the "ease of interface" principle to "favorable affordances" and considering it as the technical requirement for digital dialogic communication, we believe our model-“dialogic principles for mediated communication" as visualized in Figure 1-provides more-relevant suggestions to the real-world practice of public relations. In line with the original authors' intent of guiding communication strategies (cf. Kent \& Taylor, 1998), we deliver this conceptual expansion as a long-overdue revision to the dialogic principles that no longer fit the current media landscape.

\section{[Insert Figure 1 Here]}

This conceptual expansion is needed to equip practitioners with the necessary knowledge to differentiate popular social media platforms for organizational purposes, which the "ease of interface" principle fails to do. For example, the three major social media platforms-Facebook, Twitter, and Reddit-all have interfaces that are easy to use, and following the "ease of interface" principle does not contribute any meaningful understanding to why these platforms differ in their outcomes. Instead, examining dialogic communication practices with a "favorable affordances" principle, practitioners and scholars can have a better understanding of how these platforms' affordances lead to different digital experiences. Facebook, with its high social presence and network association affordances and low anonymity affordance, offers organizations a better chance to execute "return visit generation" and create close-knit communities through repeated interactions (e.g., Kim et al., 2014; Shin et al., 2015). Twitter's low personalization, bandwidth, and editability affordances make it suitable as a broadcasting tool for organizations, where "useful information" is paramount for eliciting interactions and building relationships that go beyond clicks and likes (e.g., Watkins, 2017; Yue et al., 2019). Reddit, with its high conversation control and persistence affordances, uses discussion posts as 
its content units and can hold in-depth conversations between organizations and their online publics (e.g., Le \& Mao, 2018). Though understudied in public communication research, the Reddit platform seems to easily fulfill the "dialogic loops" principle since organizations can readily engage in back-and-forth conversations with stakeholders, but also exposes organizations to more risks and manipulations due to its high bandwidth affordance (see Gaudette et al., 2021).

Due to its nature of being the precedent of digital public relations practice, we place the "favorable affordances" principle as the base of the new model, in a way to inform practitioners that platform opportunities should be critically gauged as the technical requirement for dialogic communication before the stage of communication strategy development.

The point is, to conduct digital dialogic communication and thus foster dialogue in the contemporary media environment, "ease of interface" is a minimum requirement, not an ideal principle. The ideal principle should be that the digital platform, chosen by practitioners to host dialogic communication, should provide favorable affordances to support such organizational efforts. Different affordances can invoke different communication behavior, and it is time to reconsider the principle and equip practitioners with the knowledge of affordances to help them understand the role of technology in their practice. We believe the conceptual expansion delivers a better framework for the digital age, not only for websites and social media, but also for newer communication technologies yet to come.

\section{Implications of Affordances for Other Areas in Public Relations Research}

Authentic dialogic communication is crucial to building mutually beneficial relationships between organizations and publics (Kent \& Taylor, 2018). Although dialogic communication does not necessarily need to be mediated by communication technology, we cannot ignore the fact that digital public relations practice is fast-growing and much of what we do today has been mediated.

We have so far identified and reviewed the struggle of adapting dialogic concepts to the current media landscape, and we have discussed how the affordance framework can improve 
the theoretical development of dialogue as a public relations theory and can inform the practical suggestions of dialogic principles as communication strategies. From a normative standpoint, it seems that mediated communication can never lead to genuine dialogue and that "digital dialogue" is a self-contradictory concept. Yet, fixating on this tension overshadows promising research directions-if digital dialogue cannot take place, why so? Instead of claiming that the dialogic theory no longer applicable to digital contexts, a change of direction may solicit new conceptual development that is necessary to characterize and theorize contemporary public relations practice. The lens of affordances, in our quest to further understand dialogue in today's technology-mediated environment, is the vantage point direly needed to not only renew and expand the dialogic theory, but also unpack opportunities in many public relations research areas. This essay's ultimate goal, despite its heavy focus on dialogue, is to bring the affordance theory into the general agenda of digital public relations research.

First and foremost, affordances can help to further research at the intersection of digital media and crisis communication. For example, scholars recently have renewed their interests in a repertoire approach to study how channel choices affect crisis communication effectiveness (e.g., Liu et al., 2019; Park et al., 2019; Schultz et al., 2011). So far, these studies have been limited to the platforms chosen by the researchers, and they have rarely touched upon the fundamental differences among platforms that are yielding these results. By connecting the affordance measurement of each platform to crisis-relevant communication outcomes, an affordance approach with platform-comparison research designs can create valuable insights for theory development related to platforms/channels combination and choices in crises. Such research agendas also better reflect crisis communication practices in the real world, where a combination of channels and platforms is utilized.

Secondly, at the intersection of digital media and issue management, affordance theory also provides an excellent opportunity to understand why certain channels are preferred over others in certain circumstances, and what affordances are utilized in those circumstances to fulfill strategic purposes. Results from these studies can help theorize the accumulating 
evidence on multi-platform digital media use in relationship building, in research areas such as nonprofit advocacy (e.g., Ihm, 2019), public diplomacy (e.g., Zhang, 2013), and corporate social responsibility (e.g., Reilly \& Hynan, 2014). More importantly, as affordances constitute the underlying principles upon which certain channels are selected, insights from such research are evergreen and applicable to future emerging platforms, and they can be used to understand the temporal changes of digital strategic management efforts throughout issue stages (see Sommerfeldt \& Yang, 2017), as well as how intended effects can be maximized based on platform affordances.

Finally, engagement is another quickly developing agenda in public relations research that can benefit from an affordance perspective, specifically as to what and how engagement outcomes can be achieved in socially mediated contexts (cf. Chewning, 2018; Johnston, 2018). The mediating digital technologies provide different action possibilities for engagement processes, which in turn translate to different engagement possibilities for organizations and stakeholders. Extending literature on socially mediated engagement, Xu and Xiong (2020) have proposed four parameters to further theorize engagement in digital contexts. These authors took notice of platform affordances, which affected moderation and control, typologies of networks, and degrees of participation and interactivity. The technical parameter discussed by $\mathrm{Xu}$ and Xiong (2020) resembles our model proposed in Figure 1, where affordance is the foundation upon which the meso-level factors determine the nature and outcomes of engagement.

The general theory of affordance is by no means promoting technological determinism, but it highlights the point that communication platforms' technical infrastructure is crucial to any mediated communication (e.g., Zhou, 2021), including digital dialogic communication. Previously, when scholars discussed dialogic communication, they mostly focused on the humanity side of the story. For example, real-world communication has power imbalances and time constraints (Lane \& Bartlett, 2016; Wirtz \& Zimbres, 2018), which usually lead to sub-optimal dialogue in the end (Lane, 2018). The affordance perspective focuses on the 
infrastructure side of the story, in that digital dialogic communication, regardless of on which communication platform it takes place, is mediated by inhuman objects, and these inhuman

objects can affect dialogue. We encourage public relations scholars to start meaningful discussions on how to better understand the term "digital" in digital dialogic communication, and using the affordance framework for these inquiries, as we argue, is one of the preferred approaches.

\section{Concluding Remarks}

Affordance, an underlying principle affecting many facets of social media platforms and mediated interactions, provides a promising framework to address extant tensions in public relations theories. We contend that the dialogic theory can still hold its relevance to today's socially mediated landscape, once it receives some overdue re-examinations informed by interdisciplinary insights based on affordances. The shift from "ease of interface" to "favorable affordances" not only is a needed expansion of the dialogic principles, but also signals a new way forward to consider the possibility of communicating dialogic orientations digitally. On a grand scale, affordance theory also presents new directions to further theorize digital public relations, particularly related to cross-platforms adaptation and utilization, an emerging area in public relations research that acknowledges and emphasizes the benefits of engaging various (mediated) communication channels to achieve strategic purposes. 


\section{References}

Allen, M. (2008). Web 2.0: An argument against convergence. First Monday, 13(3). https://doi.org/10.5210/fm.v13i3.2139

Allen, M. (2013). What was Web 2.0? Versions as the dominant mode of internet history. New Media \& Society, 15(2), 260-275. https://doi.org/10.1177/1461444812451567

Anderson, C., \& Robey, D. (2017). Affordance potency: Explaining the actualization of technology affordances. Information and Organization, 27(2), 100-115. https://doi.org/10.1016/j.infoandorg.2017.03.002

Ao, S. H., \& Huang, Q. S. (2020). A systematic review on the application of dialogue in public relations to information communication technology-based platforms: Comparing English and Chinese contexts. Public Relations Review, 46(1), 101814. https://doi.org/10.1016/j.pubrev.2019.101814

Argyris, Y. A., \& Monu, K. (2015). Corporate use of social media: Technology affordance and external stakeholder relations. Journal of Organizational Computing and Electronic Commerce, 25(2), 140-168. https://doi.org/10.1080/10919392.2015.1033940

Auger, G. A. (2013). Fostering democracy through social media: Evaluating diametrically opposed nonprofit advocacy organizations' use of Facebook, Twitter, and YouTube. Public Relations Review, 39(4), 369-376. https://doi.org/10.1016/j.pubrev.2013.07.013

Barassi, V., \& Treré, E. (2012). Does Web 3.0 come after Web 2.0? Deconstructing theoretical assumptions through practice. New Media \& Society, 14(8), 1269-1285. https://doi.org/10.1177/1461444812445878

Barreda-Ángeles, M., Aleix-Guillaume, S., \& Pereda-Baños, A. (2021). Virtual reality storytelling as a double-edged sword: Immersive presentation of nonfiction $360^{\circ}$-video is associated with impaired cognitive information processing. Communication Monographs, 88(2), 154-173. https://doi.org/10.1080/03637751.2020.1803496 
Bortree, D. S., \& Seltzer, T. (2009). Dialogic strategies and outcomes: An analysis of environmental advocacy groups' Facebook profiles. Public Relations Review, 35(3), 317-319. https://doi.org/10.1016/j.pubrev.2009.05.002

Botan, C. (1997). Ethics in strategic communication campaigns: The case for a new approach to public relations. The fournal of Business Communication, 34(2), 188-202.

Briones, R. L., Kuch, B., Liu, B. F., \& Jin, Y. (2011). Keeping up with the digital age: How the American Red Cross uses social media to build relationships. Public Relations Review, 37(1), 37-43. https://doi.org/10.1016/j.pubrev.2010.12.006

Buber, M. (1970). I and thou (W. Kaufmann, Trans.). Charles Scribner’s Sons.

Buchanan-Oliver, M., \& Fitzgerald, E. M. (2016). Industry and agency views of social media: Issues implementing dialogic communication. Journal of Marketing Communications, 22(4), 437-454. https://doi.org/10.1080/13527266.2014.975829

Cambridge University Press. (n.d.). Orientation. https:/dictionary.cambridge.org/us/dictionary/english/orientation

Campbell, S. W. (2013). Mobile media and communication: A new field, or just a new journal? Mobile Media \& Communication, 1(1), 8-13. https://doi.org/10.1177/2050157912459495

Carr, C. T. (2020). CMC Is dead, long live CMC!: Situating computer-mediated communication scholarship beyond the digital age. Journal of Computer-Mediated Communication, 25(1), 9-22. https://doi.org/10.1093/jcmc/zmz018

Chewning, L. V. (2018). Virtual engagement: A theoretical framework of affordances, networks, and communication. In K. A. Johnston \& M. Taylor (Eds.), The handbook of communication engagement (pp. 439-452). Wiley-Blackwell.

Ciszek, E. L. (2020). "We are people, not transactions": Trust as a precursor to dialogue with LGBTQ publics. Public Relations Review, 46(1), 101759. https://doi.org/10.1016/j.pubrev.2019.02.003 
Ciszek, E. L., \& Logan, N. (2018). Challenging the dialogic promise: How Ben \& Jerry’s support for Black Lives Matter fosters dissensus on social media. Journal of Public Relations Research, 30(3), 115-127. https://doi.org/10.1080/1062726X.2018.1498342

Cormode, G., \& Krishnamurthy, B. (2008). Key differences between Web 1.0 and Web 2.0. First Monday, 13(6). https://doi.org/10.5210/fm.v13i6.2125

De Luca, L. M., Herhausen, D., Troilo, G., \& Rossi, A. (2021). How and when do big data investments pay off? The role of marketing affordances and service innovation. fournal of the Academy of Marketing Science, 49(4), 790-810. https://doi.org/10.1007/s11747-020-00739-x

Deseriis, M. (2021). Rethinking the digital democratic affordance and its impact on political representation: Toward a new framework. New Media \& Society, 23(8), 2452-2473. https://doi.org/10.1177/1461444820929678

Evans, S. K., Pearce, K. E., Vitak, J., \& Treem, J. W. (2017). Explicating affordances: A conceptual framework for understanding affordances in communication research. Fournal of Computer-Mediated Communication, 22(1), 35-52. https://doi.org/10.1111/jcc4.12180

Fox, J., \& McEwan, B. (2017). Distinguishing technologies for social interaction: The perceived social affordances of communication channels scale. Communication Monographs, 84(3), 298-318. https://doi.org/10.1080/03637751.2017.1332418

Fulk, J., \& Yuan, Y. C. (2013). Location, motivation, and social capitalization via enterprise social networking. Journal of Computer-Mediated Communication, 19(1), 20-37. https://doi.org/10.1111/jcc4.12033

Gálvez-Rodríguez, M. d. M., Sáez-Martín, A., García-Tabuyo, M., \& Caba-Pérez, C. (2018). Exploring dialogic strategies in social media for fostering citizens' interactions with Latin American local governments. Public Relations Review, 44(2), 265-276. https://doi.org/10.1016/j.pubrev.2018.03.003 
Gaudette, T., Scrivens, R., Davies, G., \& Frank, R. (2021). Upvoting extremism: Collective identity formation and the extreme right on Reddit. New Media \& Society, 23(12), 3491-3508. https://doi.org/10.1177/1461444820958123

Gibson, J. J. (1979). The ecological approach to visual perception. Houghton Mifflin.

Gligorić, K., Anderson, A., \& West, R. (2018). How constraints affect content: The case of Twitter's switch from 140 to 280 characters. Proceedings of the Twelfth International AAAI Conference on Web and Social Media (ICWSM 2018), 596-599.

Greeno, J. G. (1994). Gibson's affordances. Psychological Review, 101(2), 336-342. https://doi.org/10.1037/0033-295X.101.2.336

Grunig, J. E. (2001). Two-way symetrical public relations: Past, present and future. In R. L. Heath (Ed.), Handbook of public relations (pp. 11-30). SAGE Publications.

Grunig, J. E., \& Hunt, T. (1984). Managing public relations. Holt, Rinehart and Winston.

Halpern, D., \& Gibbs, J. (2013). Social media as a catalyst for online deliberation? Exploring the affordances of Facebook and YouTube for political expression. Computers in Human Behavior, 29(3), 1159-1168. https://doi.org/10.1016/j.chb.2012.10.008

Heath, R. L., Pearce, W. B., Shotter, J., Taylor, J. R., Kersten, A., Zorn, T., Roper, J., Motion, J., \& Deetz, S. (2006). The processes of dialogue: Participation and legitimation. Management Communication Quarterly, 19(3), 341-375. https://doi.org/10.1177/0893318905282208

Huang, Y.-H. (2001). Values of public relations: Effects on organization-public relationships mediating conflict resolution. Journal of Public Relations Research, 13(4), 265-301. https://doi.org/10.1207/S1532754XJPRR1304_01

Huang, Y.-H. (2004). PRSA: Scale development for exploring the impetus of public relations strategies. Fournalism \& Mass Communication Quarterly, 81(2), 307-326.

Humphreys, L. (2007). Mobile social networks and social practice: A case study of dodgeball. Journal of Computer-Mediated Communication, 13(1), 341-360. https://doi.org/10.1111/j.1083-6101.2007.00399.x 
Ihm, J. (2019). Communicating without nonprofit organizations on nonprofits' social media: Stakeholders' autonomous networks and three types of organizational ties. New Media \& Society, 21(11-12), 2648-2670. https://doi.org/10.1177/1461444819854806

Ingenhoff, D., \& Koelling, A. M. (2009). The potential of Web sites as a relationship building tool for charitable fundraising NPOs. Public Relations Review, 35(1), 66-73. https://doi.org/10.1016/j.pubrev.2008.09.023

Jaidka, K., Zhou, A., \& Lelkes, Y. (2019). Brevity is the soul of Twitter: The constraint affordance and political discussion. Journal of Communication, 69(4), 345-372. https://doi.org/10.1093/joc/jqz023

Jarrett, K. (2008). Interactivity is evil! A critical investigation of Web 2.0. First Monday, 13(3). https://doi.org/10.5210/fm.v13i3.2140

Johnston, K. A. (2018). Toward a theory of social engagement. In K. A. Johnston \& M. Taylor (Eds.), The handbook of communication engagement (pp. 19-32). Wiley-Blackwell.

Joyce, C. K. (2009). The blank page: Effects of constraint on creativity (Doctoral dissertation). University of California, Berkeley. Berkeley, CA. http://dx.doi.org/10.2139/ssrn.1552835

Kent, M. L., \& Lane, A. B. (2017). A rhizomatous metaphor for dialogic theory. Public Relations Review, 43(3), 568-578. https://doi.org/10.1016/j.pubrev.2017.02.017

Kent, M. L., \& Li, C. (2020). Toward a normative social media theory for public relations. Public Relations Review, 46(1), 101857. https://doi.org/10.1016/j.pubrev.2019.101857

Kent, M. L., \& Saffer, A. J. (2014). A Delphi study of the future of new technology research in public relations. Public Relations Review, 40(3), 568-576. https://doi.org/10.1016/j.pubrev.2014.02.008

Kent, M. L., \& Taylor, M. (1998). Building dialogic relationships through the world wide web. Public Relations Review, 24(3), 321-334. https://doi.org/10.1016/S0363-8111(99)80143-X Kent, M. L., \& Taylor, M. (2002). Toward a dialogic theory of public relations. Public Relations Review, 28(1), 21-37. https://doi.org/10.1016/S0363-8111(02)00108-X 
Kent, M. L., \& Taylor, M. (2018). Understanding the rhetoric of dialogue and the dialogue of rhetoric. In Ø. Ihlen \& R. L. Heath (Eds.), The handbook of organizational rhetoric and communication (pp. 315-327). John Wiley \& Sons, Inc. https://doi.org/10.1002/9781119265771.ch22

Kent, M. L., \& Theunissen, P. (2016). Elegy for mediated dialogue: Shiva the destroyer and reclaiming our first principles. International fournal of Communication, 10, 4040-4054.

Kim, D., Chun, H., Kwak, Y., \& Nam, Y. (2014). The employment of dialogic principles in website, Facebook, and Twitter platforms of environmental nonprofit organizations. Social Science Computer Review, 32(5), 590-605. https://doi.org/10.1177/0894439314525752

Kuhn, T. (2010). The structure of scientific revolutions. In M. Ruse (Ed.), Philosophy after Darwin (pp. 176-177). Princeton University Press. https://doi.org/10.1515/9781400831296-024

Lane, A. B. (2018). If it's so good, why not make them do it? Why true dialogue cannot be mandated. Public Relations Review, 44(5), 656-666. https://doi.org/10.1016/j.pubrev.2018.10.001

Lane, A. B. (2020). The dialogic ladder: Toward a framework of dialogue. Public Relations Review, 46(1), 101870. https://doi.org/10.1016/j.pubrev.2019.101870

Lane, A. B., \& Bartlett, J. L. (2016). Why dialogic principles don't make it in practice-and what we can do about it. International fournal of Communication, 10, 4074-4094.

Le, P. H., \& Mao, Y. (2018). Reddit as a new platform for public relations: Organizations' use of dialogic principles and their publics' responses in the subreddit IAmA. First Monday, 23(11). https://doi.org/10.5210/fm.v23i11.8131

Leidner, D. E., Gonzalez, E., \& Koch, H. (2018). An affordance perspective of enterprise social media and organizational socialization. The Journal of Strategic Information Systems, 27(2), 117-138. https://doi.org/10.1016/j.jsis.2018.03.003

Lelkes, Y. (2020). A bigger pie: The effects of high-speed Internet on political behavior. fournal of Computer-Mediated Communication, 25(3), 199-216. https://doi.org/10.1093/jcmc/zmaa002 
Leonardi, P. M., \& Vaast, E. (2017). Social media and their affordances for organizing: A review and agenda for research. Academy of Management Annals, 11(1), 150-188. https://doi.org/10.5465/annals.2015.0144

Linvill, D. L., McGee, S. E., \& Hicks, L. K. (2012). Colleges' and universities' use of Twitter: A content analysis. Public Relations Review, 38(4), 636-638. https://doi.org/10.1016/j.pubrev.2012.05.010

Liu, B. F., Xu, S., Lim, J. R., \& Egnoto, M. (2019). How publics' active and passive communicative behaviors affect their tornado responses: An integration of STOPS and SMCC. Public Relations Review, 45(4), 101831. https://doi.org/10.1016/j.pubrev.2019.101831

Lovejoy, K., \& Saxton, G. D. (2012). Information, community, and action: How nonprofit organizations use social media. fournal of Computer-Mediated Communication, 17(3), 337-353. https://doi.org/10.1111/j.1083-6101.2012.01576.x

Lovejoy, K., Waters, R. D., \& Saxton, G. D. (2012). Engaging stakeholders through Twitter: How nonprofit organizations are getting more out of 140 characters or less. Public Relations Review, 38(2), 313-318. https://doi.org/10.1016/j.pubrev.2012.01.005

Maia, R. C. M., \& Rezende, T. A. S. (2016). Respect and disrespect in deliberation across the networked media environment: Examining multiple paths of political talk. fournal of Computer-Mediated Communication, 21(2), 121-139. https://doi.org/10.1111/jcc4.12155

Mao, C. M., \& DeAndrea, D. C. (2019). How anonymity and visibility affordances influence employees' decisions about voicing workplace concerns. Management Communication Quarterly, 33(2), 160-188. https://doi.org/10.1177/0893318918813202

McAllister-Spooner, S. M. (2009). Fulfilling the dialogic promise: A ten-year reflective survey on dialogic Internet principles. Public Relations Review, 35(3), 320-322. https://doi.org/10.1016/j.pubrev.2009.03.008

McCormick, E. (2021). Snapchat widens lead over TikTok, Instagram as teens' favorite social media app: Piper Sandler. https://finance.yahoo.com/news/snapchat-widens-lead-overtik-tok-instagram-as-teens-favorite-social-media-app-piper-sandler-145605293.html 
Men, L. R., Tsai, W.-H. S., Chen, Z. F., \& Ji, Y. G. (2018). Social presence and digital dialogic communication: Engagement lessons from top social CEOs. Fournal of Public Relations Research, 30(3), 83-99. https://doi.org/10.1080/1062726X.2018.1498341

Merriam-Webster. (n.d.). Principle. https://www.merriam-webster.com/dictionary/principle

O'Reilly, T. (2005). What is Web 2.0: Design patterns and business models for the next generation of software. https://www.oreilly.com/pub/a//web2/archive/what-is-web-20.html

O’Sullivan, B. (2000). What you don't know won't hurt me: Impression management functions of communication channels in relationships. Human Communication Research, 26(3), 403-431. https://doi.org/10.1111/j.1468-2958.2000.tb00763.x

Paek, H.-J., Hove, T., Jung, Y., \& Cole, R. T. (2013). Engagement across three social media platforms: An exploratory study of a cause-related PR campaign. Public Relations Review, 39(5), 526-533. https://doi.org/10.1016/j.pubrev.2013.09.013

Pang, A., Shin, W., Lew, Z., \& Walther, J. B. (2018). Building relationships through dialogic communication: Organizations, stakeholders, and computer-mediated communication. Journal of Marketing Communications, 24(1), 68-82. https://doi.org/10.1080/13527266.2016.1269019

Park, S., Boatwright, B., \& Avery, E. J. (2019). Information channel preference in health crisis: Exploring the roles of perceived risk, preparedness, knowledge, and intent to follow directives. Public Relations Review, 45(5), 101794. https://doi.org/10.1016/j.pubrev.2019.05.015

Pearson, R. (1989a). Business ethics as communication ethics: Public relations practice and the idea of dialogue. In C. H. Botan \& V. Hazleton (Eds.), Public relations theory (pp. 111-131). Erlbaum.

Pearson, R. (1989b). A theory of public relations ethics (Doctoral dissertation). Ohio University. Athens, OH. https://doi.org/10.4324/9781351225748 
Qu, Y. (2020). Engaging publics in the mobile era: A study of Chinese charitable foundations' use of WeChat. Public Relations Review, 46(1), 101815. https://doi.org/10.1016/j.pubrev.2019.101815

Reilly, A. H., \& Hynan, K. A. (2014). Corporate communication, sustainability, and social media: It's not easy (really) being green. Business Horizons, 57(6), 747-758. https://doi.org/10.1016/j.bushor.2014.07.008

Rhee, Y. (2002). Global public relations: A cross-cultural study of the excellence theory in South Korea. Journal of Public Relations Research, 14(3), 159-184. https://doi.org/10.1207/S1532754XJPRR1403_1

Rice, R. E., Evans, S. K., Pearce, K. E., Sivunen, A., Vitak, J., \& Treem, J. W. (2017). Organizational media affordances: Operationalization and associations with media use. fournal of Communication, 67(1), 106-130. https://doi.org/10.1111/jcom.12273

Romenti, S., Valentini, C., Murtarelli, G., \& Meggiorin, K. (2016). Measuring online dialogic conversations' quality: A scale development. Journal of Communication Management, 20(4), 328-346. https://doi.org/10.1108/JCOM-11-2015-0090

Rossini, P. (2020). Beyond incivility: Understanding patterns of uncivil and intolerant discourse in online political talk. Communication Research. https://doi.org/10.1177/0093650220921314

Russmann, U., \& Lane, A. B. (2020). Mandating dialogue? International perspectives on differences between theory and practice. Public Relations Review, 46(1), 101819. https://doi.org/10.1016/j.pubrev.2019.101819

Rybalko, S., \& Seltzer, T. (2010). Dialogic communication in 140 characters or less: How Fortune 500 companies engage stakeholders using Twitter. Public Relations Review, 36(4), 336-341. https://doi.org/10.1016/j.pubrev.2010.08.004

Scholz, J., \& Smith, A. N. (2016). Augmented reality: Designing immersive experiences that maximize consumer engagement. Business Horizons, 59(2), 149-161. https://doi.org/10.1016/j.bushor.2015.10.003 
Schultz, F., Utz, S., \& Göritz, A. (2011). Is the medium the message? Perceptions of and reactions to crisis communication via twitter, blogs and traditional media. Public Relations Review, 37(1), 20-27. https://doi.org/10.1016/j.pubrev.2010.12.001

Seltzer, T., \& Mitrook, M. A. (2007). The dialogic potential of weblogs in relationship building. Public Relations Review, 33(2), 227-229. https://doi.org/10.1016/j.pubrev.2007.02.011

Sha, B.-L. (2007). Dimensions of public relations: Moving beyond traditional public relations models. In S. C. Duhé (Ed.), New media and public relations (pp. 3-25). Peter Lang.

Sha, B.-L. (2009). Exploring the connection between organizational identity and public relations behaviors: How symmetry trumps conservation in engendering organizational identification. Fournal of Public Relations Research, 21(3), 295-317. https://doi.org/10.1080/10627260802640765

Shin, W., Pang, A., \& Kim, H. J. (2015). Building relationships through integrated online media: Global organizations' use of brand web sites, Facebook, and Twitter. Fournal of Business and Technical Communication, 29(2), 184-220. https://doi.org/10.1177/1050651914560569

Sommerfeldt, E. J., \& Xu, S. (2017). Making a "difference" with digital media? The evaluation perspectives, practices, and challenges of Chinese NGOs. Chinese fournal of Communication, 10(1), 89-107. https://doi.org/10.1080/17544750.2016.1210184

Sommerfeldt, E. J., \& Yang, A. (2017). Relationship networks as strategic issues management: An issue-stage framework of social movement organization network strategies. Public Relations Review, 43(4), 829-839. https://doi.org/10.1016/j.pubrev.2017.06.012

Sommerfeldt, E. J., \& Yang, A. (2018). Notes on a dialogue: Twenty years of digital dialogic communication research in public relations. Fournal of Public Relations Research, 30(3), 59-64. https://doi.org/10.1080/1062726X.2018.1498248

Sommerfeldt, E. J., Yang, A., \& Taylor, M. (2019). Public relations channel "repertoires": Exploring patterns of channel use in practice. Public Relations Review, 45(4), 101796. https://doi.org/10.1016/j.pubrev.2019.101796 
Steffen, J. H., Gaskin, J. E., Meservy, T. O., Jenkins, J. L., \& Wolman, I. (2019). Framework of affordances for virtual reality and augmented reality. Fournal of Management Information Systems, 36(3), 683-729. https://doi.org/10.1080/07421222.2019.1628877

Stewart, J. (1978). Foundations of dialogic communication. Quarterly fournal of Speech, 64(2), 183-201. https://doi.org/10.1080/00335637809383424

Sundar, S. S. (2008). The MAIN model: A heuristic approach to understanding technology effects on credibility. In M. J. Metzger \& A. J. Flanagin (Eds.), Digital media, youth, and credibility (pp. 73-100). MIT Press.

Taylor, M. (2011). Building social capital through rhetoric and public relations. Management Communication Quarterly, 25(3), 436-454. https://doi.org/10.1177/0893318911410286

Taylor, M., \& Kent, M. L. (2014). Dialogic engagement: Clarifying foundational concepts. fournal of Public Relations Research, 26(5), 384-398. https://doi.org/10.1080/1062726X.2014.956106

Taylor, M., Kent, M. L., \& White, W. J. (2001). How activist organizations are using the Internet to build relationships. Public Relations Review, 27(3), 263-284. https://doi.org/10.1016/S0363-8111(01)00086-8

Theunissen, P. (2015). The quantum entanglement of dialogue and persuasion in social media: Introducing the per-di principle. Atlantic fournal of Communication, 23(1), 5-18. https://doi.org/10.1080/15456870.2015.972405

Theunissen, P., \& Wan Noordin, W. N. (2012). Revisiting the concept "dialogue" in public relations. Public Relations Review, 38(1), 5-13. https://doi.org/10.1016/j.pubrev.2011.09.006

Treem, J. W., \& Leonardi, P. M. (2013). Social media use in organizations: Exploring the affordances of visibility, editability, persistence, and association. Annals of the International Communication Association, 36(1), 143-189. https://doi.org/10.1080/23808985.2013.11679130

Wang, Y., \& Yang, Y. (2020). Dialogic communication on social media: How organizations use Twitter to build dialogic relationships with their publics. Computers in Human Behavior, 104, 106183. https://doi.org/10.1016/j.chb.2019.106183 
Watkins, B. A. (2017). Experimenting with dialogue on Twitter: An examination of the influence of the dialogic principles on engagement, interaction, and attitude. Public Relations Review, 43(1), 163-171. https://doi.org/10.1016/j.pubrev.2016.07.002

Wirtz, J. G., \& Zimbres, T. M. (2018). A systematic analysis of research applying 'principles of dialogic communication' to organizational websites, blogs, and social media: Implications for theory and practice. Journal of Public Relations Research, 30(1-2), 5-34. https://doi.org/10.1080/1062726X.2018.1455146

Wohn, D. Y., Carr, C. T., \& Hayes, R. A. (2016). How affective is a "like"?: The effect of paralinguistic digital affordances on perceived social support. Cyberpsychology, Behavior, and Social Networking, 19(9), 562-566. https://doi.org/10.1089/cyber.2016.0162

Xiong, Y., Cho, M., \& Boatwright, B. (2019). Hashtag activism and message frames among social movement organizations: Semantic network analysis and thematic analysis of Twitter during the \#MeToo movement. Public Relations Review, 45(1), 10-23. https://doi.org/10.1016/j.pubrev.2018.10.014

Xu, S., \& Xiong, Y. (2020). Setting socially mediated engagement parameters: A topic modeling and text analytic approach to examining polarized discourses on Gillette's campaign. Public Relations Review, 46(5), 101959. https://doi.org/10.1016/j.pubrev.2020.101959

Xu, S., \& Zhou, A. (2020). Hashtag homophily in twitter network: Examining a controversial cause-related marketing campaign. Computers in Human Behavior, 102, 87-96. https://doi.org/10.1016/j.chb.2019.08.006

Yang, S.-U., Kang, M., \& Cha, H. (2015). A study on dialogic communication, trust, and distrust: Testing a scale for measuring organization-public dialogic communication (OPDC). Journal of Public Relations Research, 27(2), 175-192. https://doi.org/10.1080/1062726X.2015.1007998

Yuan, E. (2011). News consumption across multiple media platforms: A repertoire approach. Information, Communication \& Society, 14(7), 998-1016. https://doi.org/10.1080/1369118X.2010.549235 
Yue, C. A., Qin, Y. S., Vielledent, M., Men, L. R., \& Zhou, A. (2021). Leadership going social: How U.S. nonprofit executives engage publics on Twitter. Telematics and Informatics, 65, 101710. https://doi.org/10.1016/j.tele.2021.101710

Yue, C. A., Thelen, P., Robinson, K., \& Men, L. R. (2019). How do CEOs communicate on Twitter? A comparative study between Fortune 200 companies and top startup companies. Corporate Communications: An International fournal, 24(3), 532-552. https://doi.org/10.1108/CCIJ-03-2019-0031

Zhang, J. (2013). A strategic issue management (SIM) approach to social media use in public diplomacy. American Behavioral Scientist, 57(9), 1312-1331. https://doi.org/10.1177/0002764213487734

Zhou, A. (2021). Causal effects of affordance change on communication behavior: Empirical evidence from organizational and leadership social media use. Telematics and Informatics, 59, 101549. https://doi.org/10.1016/j.tele.2020.101549 
Table 1

Dialogic Concepts Examined from the Lens of Affordances

\begin{tabular}{|c|c|c|c|c|}
\hline Term & Type & Definition & Key References & Inquiries from an Affordance Perspective \\
\hline Dialogue & Orientations & $\begin{array}{l}\text { A communicative } \\
\text { orientation that features } \\
\text { risk, mutuality, } \\
\text { propinquity, empathy, } \\
\text { and commitment. }\end{array}$ & $\begin{array}{l}\text { Buber (1970) } \\
\text { Stewart (1978) } \\
\text { Pearson }(1989 a, 1989 b) \\
\text { Kent \& Taylor (2002) } \\
\text { Heath et al. (2006) } \\
\text { Theunissen \& Wan } \\
\text { Noordin (2012) }\end{array}$ & $\begin{array}{l}\text { What affordances support and } \\
\text { impede the communication of risk, } \\
\text { mutuality, propinquity, empathy, } \\
\text { and commitment? }\end{array}$ \\
\hline $\begin{array}{l}\text { Dialogic } \\
\text { Communication }\end{array}$ & $\begin{array}{l}\text { Practice with } \\
\text { orientations }\end{array}$ & $\begin{array}{l}\text { Communication practice } \\
\text { that builds and sustains } \\
\text { dialogues between } \\
\text { organizations and } \\
\text { publics. }\end{array}$ & $\begin{array}{l}\text { Yang et al. (2015) } \\
\text { Buchanan-Oliver \& } \\
\text { Fitzgerald (2016) } \\
\text { Lane \& Bartlett (2016) } \\
\text { Ciszek \& Logan (2018) }\end{array}$ & $\begin{array}{l}\text { - What affordances support and } \\
\text { impede relationship building } \\
\text { through digital channels? } \\
\text { - Do affordances interact to affect } \\
\text { relational outcomes of digital } \\
\text { public relations practice? }\end{array}$ \\
\hline $\begin{array}{l}\text { Digital } \\
\text { Dialogic } \\
\text { Principles }\end{array}$ & $\begin{array}{l}\text { Principles } \\
\text { for practice }\end{array}$ & $\begin{array}{l}\text { Dialogic Loops } \\
\text { Useful Information } \\
\text { Visitor Conservation } \\
\text { Return Visit Generation } \\
\text { Ease of Interface }\end{array}$ & $\begin{array}{l}\text { Kent \& Taylor (1998) } \\
\text { McAllister-Spooner } \\
(2009) \\
\text { Wirtz \& Zimbres (2018) } \\
\text { Ao \& Huang (2020) }\end{array}$ & 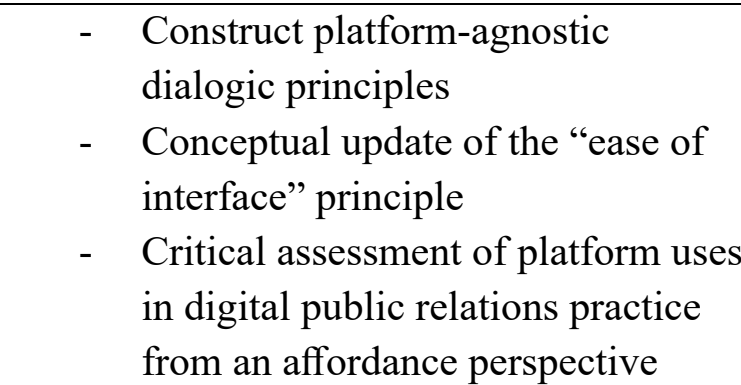 \\
\hline
\end{tabular}


Figure 1

The Construction of Dialogic Principles for Mediated Communication

A. Dialogic Principles (Kent \& Taylor, 1998)

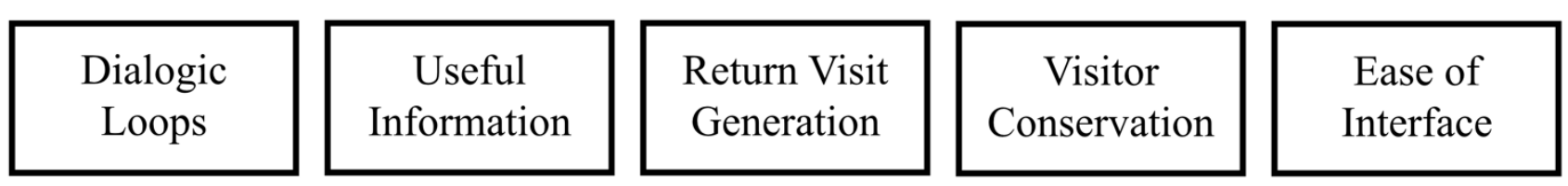

B. Conceptual Expansion of the "Ease of Interface" Principle

\begin{tabular}{|c|c|c|c|c|}
\hline $\begin{array}{l}\text { Dialogic } \\
\text { Loops }\end{array}$ & $\begin{array}{c}\text { Useful } \\
\text { Information }\end{array}$ & $\begin{array}{l}\text { Return Visit } \\
\text { Generation }\end{array}$ & $\begin{array}{c}\text { Visitor } \\
\text { Conservation }\end{array}$ & $\begin{array}{l}\text { Favorable } \\
\text { Affordances }\end{array}$ \\
\hline
\end{tabular}

C. Repositioning the "Favorable Affordances" Principle

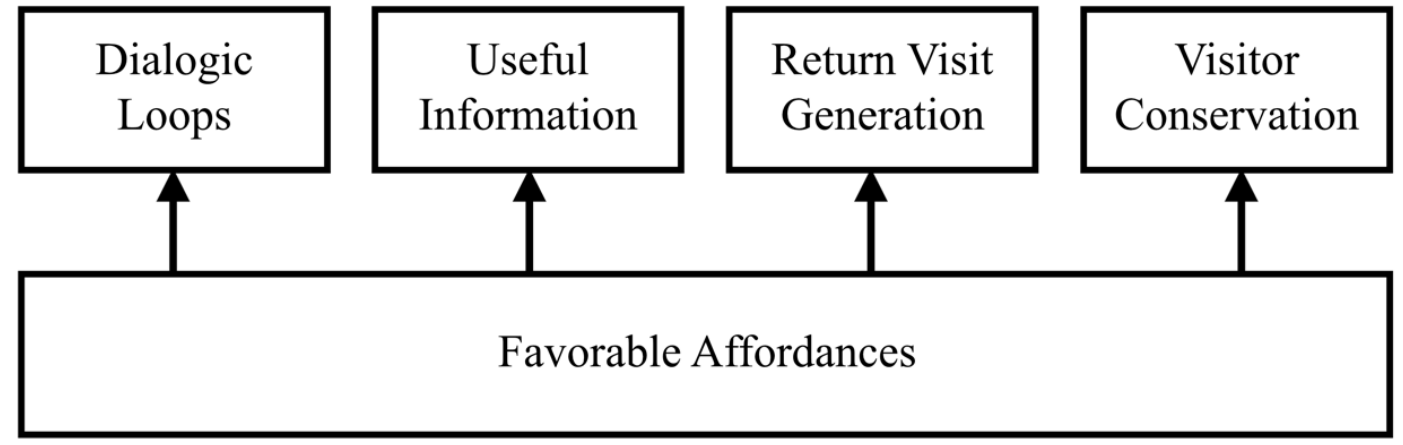

Note: Panel A shows the original dialogic principles proposed by Kent and Taylor (1998). Panel B shows the current article's conceptual expansion of the "ease of interface" principle to "favorable affordances." Panel C shows the current article's repositioning of the "favorable affordances" principle to indicate that favorable affordances constitute the technical foundation for digital dialogic communication practice, and that platform affordances should be critically gauged before the stage of communication strategy development. 